\title{
Metrical Psalmody and the Bannatyne Manuscript: Robert Pont's Psalm 83
}

\author{
JAMIE REID-BAXTER \\ University of Glasgow
}

Cet article remet dans son contexte, ou plutôt dans ses contextes, la paraphrase métrique du psaume 83 écrite par Robert Pont pour le premier psautier métrique de l'Église reformée écossaise (1564). On y montre que cette paraphrase constitue le seul lien textuel entre les trois grands receuils de vers qui virent le jour dans l'Écosse des années 1560, après le triomphe de la Réforme, à savoir, les Gude and Godlie Ballatis, le Psautier officiel, et le manuscrit Bannatyne. Cet article décrit ces trois contextes fort différents, et montre que dans chacun d'eux, le psaume 83 incarne un concept bien différencié de la continuité au sein des bouleversements et les incertitudes de l'époque.

\section{Introduction}

$\mathrm{T}$ his essay seeks to account for the prominent position in the Bannatyne Manuscript (1565-68) of the metrical paraphrase of Ps 83 made for the Kirk's official psalter of 1564 by the distinguished minister and writer Mr Robert Pont (1524-1606). This paraphrase, as Appendix A shows, is a reworking of an earlier paraphrase now to be found in Ane Compendius Buik of Godlie Psalmes and Spirituall Sangis, generally known as The Gude and Godlie Ballatis. Pont's Ps 83 constitutes the sole textual link between the Ballatis, the metrical psalter, and the Bannatyne Manuscript. ${ }^{1}$ In each of these contexts, the psalm's Janus-like presence represents a particular way of conceiving orderly, meaningful continuity amid the upheavals and uncertainties of the time.

The Gude and Godlie Ballatis is a Scots-language collection of Lutheran catechetical material, hymns, and psalm paraphrases, followed by a ragbag of contrafacta, protestant propaganda songs and anti-Roman satirical verses. Since the earliest known edition of the Ballatis dates from as late as $1565,{ }^{2}$ the stages by which all this disparate material gradually came together are unknown, but it is generally agreed that much of it had been in oral and manuscript circulation long before the Reformation of $1559-60 .^{3}$ Lutheranism had arrived in Scotland early on, thanks 
to the presence of Scots graduates and students in mainland Europe, and two of the main points of entry appear to have been the east-coast ports of Dundee and nearby St Andrews, the latter the kingdom's ecclesiastical capital and seat of its oldest university. The Ballatis' specifically Lutheran material is traditionally associated with John Wedderburn of Dundee, a St Andrews graduate and priest who had fled to Germany c.1540 and "translated manie of Luther's dytements into Scotish meeter, and the Psalmes of David," according to the presbyterian historian David Calderwood. ${ }^{4}$ As printed in 1565, the Ballatis contained a total of 23 psalm paraphrases; of these, 21 were in Scots and appeared in all the successive editions issued down to $1621.5^{5}$ There is no consistency in the way these anonymous psalms were paraphrased. For example, Ps 31 consists only of verses 1-5, concisely versified, but Ps 51 is incrusted with devotional tropes and provided with a refrain. ${ }^{6}$ However, only Ps 83 contains polemical tropes specifically attacking the Roman Church as the enemy of the Chosen Israel. The Ballatis collection as a whole has generated a certain amount of scholarship, ${ }^{8}$ but the psalm paraphrases have merited little comment from literary scholars and ecclesiastical historians. ${ }^{9}$ No work seems to have been done on investigating what tunes the Ballatis psalms were sung to since A. F. Mitchell's 1897 edition, which points out that Ps 83 was sung to the same melody as the 1564 official text. ${ }^{10}$

We do not know the full details of the difficulties and consultations that delayed the new Kirk's metrical psalter until late in $1564 ;^{11}$ that psalter was replaced in 1650 by the one still sung today. The 1564 psalms were sung by Scots through nine stirring and restless decades of enormous change; but ecclesiastical writers on the psalms in Scotland, dazzled by their conviction that the 1650 book is the ne plus ultra of metrical psalmody in any language, have had very much less to say than we might expect about its predecessor.${ }^{12}$ While the 1564 psalter's 105 melodies have received some attention from musicologists, ${ }^{13}$ historians have so far had almost nothing to say about the book. ${ }^{14}$ And though quotations from the 1564 psalter can be found embedded in post-Reformation Scottish poetry ${ }^{15}$ — even in at least four poems by the Catholic Alexander Montgomerie ${ }^{16}$ _literary scholars tend to ignore the psalter, cavalierly dismissing it as "Sternhold and Hopkins," i.e. the English Whole Booke of Psalmes of $1562^{17}$ — which it is decidedly not.

The Bannatyne Manuscript, by contrast, is extremely well known to literary scholars. Historians too acknowledge the importance of this vast, highly organized collection of vernacular verse ${ }^{18}$ - the major and often sole source for much of the poetry it contains - though to date it seems not to have aroused the specific interest of church historians. Yet as Alasdair MacDonald has adumbrated, as part 
of his longstanding argument that George Bannatyne's final text was designed for publication, the Manuscript directly reflects the religious and political situation of the 1560 s, not least in terms of the way Catholic references were selectively censored, with an eye to the collection's potential readership. ${ }^{19}$ Bannatyne, a young member of an extremely well-connected Edinburgh family, ${ }^{20}$ assembled and organized his collection in stages between 1565 and 1568, amid the uncertainties and indeed chaotic violence experienced by the fledgling Reformed Scottish polity in the latter half of the brief personal rule of the Catholic Mary, Queen of Scots. The initial scheme, possibly inspired by the royal wedding of 1565 , was for an anthology of amatory poetry, but the scope was enlarged to provide systematic coverage of other genres. By opening the completed collection with 42 folios of "Ballatis of Theoligie," followed by 53 folios of "very singular ballatis full of wisdome and moralitie etc," Bannatyne created a solid context of eternal verities and established values in which to read the worldly sections of comic, amatory and fable poetry which follow. The inclusion of Catholic religious verse, censored or otherwise, and the striking omission of overtly Reformed material, reveal a conscious attempt to maintain continuity with the culture of pre-Reformation Scotland in a world in flux and disorder. Alasdair MacDonald has written that Bannatyne "was conceivably impelled by the grand idea of offering to the new age a cultural repertory tailored to its new needs." ${ }^{21}$

As far as religious verse was concerned, Bannatyne's view of those new needs consisted largely of shoring fragments against ruin: his "Ballatis of Theoligie" consist mostly of pre-Reformation religious lyrics, their unequivocally Catholic references lightly censored. Not one text is taken even from the Lutheran sections of The Gude and Godlie Ballatis, whose concise and effective version of "Christe qui lux es et dies," for example, is ignored in favour of a floridly troped pre-Reformation version. There are indeed metrical versions of Ps 1 and Ps 51, but these stem not from the new Kirk Psalter, but from the pen of the leading poet Alexander Scott, a Bannatyne family friend. ${ }^{22}$ In such a quasi-Erasmian atmosphere, the prominent presence of Robert Pont's official Psalter text of Ps.83 is all the more striking and we shall return to it in our conclusion.

\section{The Kirk and metrical psalmody}

The Genevan leaders of the new Reformit Kirk had no more time for Luther than did Calvin, and it is therefore a curious fact that the post-1560 Kirk's Calvinist clergy allowed (or were unable to prevent) the regular reprinting, right down to 1621, of the Lutheran material which is such a feature of the Gude and Godlie Ballatis. ${ }^{23}$ 
However, there is no evidence that the Kirk, during the four-year gap when there was no officially-sanctioned kirk psalter available for use in worship, made use of the existing Scots psalm paraphrases contained in the Ballatis. Yet all of them were presumably familiar to the godly minority who were actively in favour of religious reformation; John Knox actually records the "Wedderburn" Ps 51 as having being sung by George Wishart in $1546 .{ }^{24}$ The Ballatis' Scots-language Lutheran "office hymns," carols and canticles, as opposed to the psalms, never had any chance of being adopted for liturgical use-John Knox, and a large part of the English exile congregation in Frankfurt, had famously refused to use Cranmer's 1552 Prayerbook as not being in accordance with the Word of God, and had moved en masse to psalmsinging Geneva. A decade later, the newly established Scottish Kirk, in an identical pursuit of liturgical purity, had restricted liturgical worship to (unaccompanied) unison psalms, and proceeded to abolish Christmas and Easter.

It has been shown that the often striking Ballatis psalms were mostly translated from Lutheran vernacular versions, ${ }^{25}$ rather than the original Hebrew. While a sola Scriptura Kirk, whose Bible was the product of the Hebrew and Greek scholarship of the Marian exiles in Geneva, would have looked askance at rather free paraphrases deriving from vernacular versions, that does not explain why there was no attempt to scotticise the existing Anglo-Genevan psalms. Presumably the decision to have an English-language psalter reflects godly aspirations to ever greater conformity with a reformed England where what we now know as "puritanism" was fully expected to eradicate the last vestiges of unacceptable "popery." Scotland's loss was both literary and linguistic. Unlike the Ballatis paraphrases, the psalter of 1564 betrays no sign of aspiring to, let alone achieving, poetic merit, and it is unequivocally an English-language production. One wonders what (if anything) ordinary, illiterate Scots, long used to viewing England as "the auld inimy," made of having to sing the praise of God in what was, after all, still very much a foreign, if closely-related language. ${ }^{26}$ Even though nobody would have been trying to pronounce the texts as English, rhyme is an important mnemonic device, and many of the English rhymes in the 1564 Psalter simply do not work in Scots.

Behind the Psalter's rejection of the Scots language lie both the Scottish reform movement's commitment to the newfound "amity" with reformed England, and the Anglo-Genevan experience of John Knox and his right-hand man, Christopher Goodman, minister of St Andrews. As pastors of the radical English Marian exiles who removed from Frankfurt to Geneva, Knox and Goodman had been committed to the liturgical use of the existing small body of English metrical psalms. The Anglo-Genevans may have vehemently disagreed with the other Marian exiles 
concerning the use of the 1552 Prayerbook as an expression of solidarity with the suffering Protestants of England, but singing the 37 consummately unpoetic psalm paraphrases of Thomas Sternhold was a different matter. Around them in Geneva, the exiles constantly heard the incomparable Huguenot Psalter, well on its way to completion, with its 125 "proper tunes" and its beautiful texts in variegated poetic metres and stanza forms by Clément Marot and Theodore Beza. ${ }^{27}$ Sternhold's simple ballad stanzas and homespun language represented an entirely different standard of psalm versification, but as the exiles strove to complete Sternhold's work, they introduced metrical and musical variety by taking over not a few of the splendid, dancing tunes of the French psalms, which Elizabeth Tudor would acidly dismiss as "Genevan jigs." 28 Given how small the Genevan community was, it is unsurprising, if regrettable, that after Elizabeth's accession the new English protestant establishment excluded most of these versions (by William Kethe and William Whittingham) from the English Whole Booke of Psalmes of 1562 in favour of far from dance-like "common metre" doggerel versions - mostly the work of Sternhold's admiring continuator, John Hopkins, with a further 26 from Cranmer's son-in-law Thomas Norton, co-author with Thomas Sackville of Gorboduc (1561) and translator of Calvin's Institutes. Although The Whole Booke contains not only the 150 psalms, but also 21 "hymns and canticles," it provides only 68 tunes for the lot.

The Scottish Psalter of 1564, however, provided 105 "proper tunes" for the psalms - and its text was squarely based on the earlier, incomplete psalters produced in Geneva, thus guaranteeing a surprisingly large number of rhythmically interesting melodies and poetic metres. To fill the remaining gaps, the Kirk accepted six of Norton's versions for the Whole Booke, two of John Marckant's four, and various of the English tunes. However, it also commissioned 21 new paraphrases - in English, bien sûr!-from two of its none-too-numerous first crop of ministers. ${ }^{29}$ Fifteen paraphrases, mostly to French tunes, were made by John Craig, an ex-Dominican who had become a protestant thanks to reading Calvin's Institutes in his monastery in Bologna..$^{30}$ Robert Pont, who had clearly embraced Protestantism well before 1560, versified Psalms 57, 59, 76, 80, 81 and 83 .

\section{Robert Pont}

At present, Pont is almost better known for being the father of the cartographer Timothy Pont ${ }^{31}$ than in his own right, but with ongoing scholarly work on the reformed Scottish polity, that is changing. ${ }^{2}$ Robert was a remarkable man by any reckoning. Born in Culross in 1524, his family had strong connections with the Cis- 
tercian abbey there. ${ }^{33}$ He studied at St Leonard's College in St Andrews from 1544, where the Wedderburn brothers had studied before him. Like John Wedderburn, Pont drank deep of the heterodox waters of "St Leonards Well." Already an elder of the very first kirk session in St Andrews in 1559, in December 1560 Pont was also a member of the first General Assembly. After a brief spell as minister of Dunblane and Dunkeld, he was Commissioner for Moray until 1574, as well as Provost of the Trinity College Kirk, Edinburgh, from 1571. In 1572, with the ageing Knox's backing, Pont together with John Winram, superintendent of Fife, presented articles to the General Assembly, concerning, inter alia, the role of bishops. ${ }^{34}$ Between 1572 and 1583, uniquely in the annals of the Kirk, Pont sat on the bench as a Lord of Session, and from 1574 to his death in 1606 he was the distinguished minister of St Cuthberts, in the shadow of Edinburgh Castle.

His removal from the bench in 1583 was a result of his leading role in ministerial opposition to the policies of the régime headed by James vi's favourite, James Stewart, Earl of Arran. Pont made an important public declaration against the Black Acts of 1584,35 before fleeing to England like various other leading ministers. Ironically, the dispute over the significance of clergy signatures assenting to the Black Acts left Pont and his erstwhile fellow psalm versifier, John Craig, on radically opposed sides. Both men had written catechisms for the young; Pont's Parvus Catechismus in Latin verse had been printed in St Andrews in 1573. While a senator of the College of Justice, Pont had found time to make the complex calendrical calibrations which occupy several pages of the introductory section of Bassandyne's 1579 Edinburgh printing of the Geneva Bible. Twenty years later, having in the meantime refused the offer of the bishopric of Caithness in 1587, he brought out Three Sermons against Sacrilege, a savage and learned attack on aristocratic greed for the church's revenues: "from the year of our Lorde 1560 . vnto this present time, the greatest study of all men of power of this land, hes bene [...] to spoyle the Kirk of Christ of her patrimonie [...] to the detriment of and hurte of the Kirke, the schooles, and the poore." ${ }^{6}$ Pont denounces the fact that such avarice "giues ouer-good occasion to Papistes to [...] affirme, that many Princes, Noble-men, Earles and Baronnes, haue casten off the yoke of the Romane Kirk, that they may the more freely invade and possess at their pleasure the Kirk goods." 37 The venerable minister's last publication in his long lifetime was the dialogue De Unione Regnorum Britanniae (Edinburgh, 1604), which he crowned with two vigorous Latin poems in praise of a protestant United Kingdom which would be the terror of the Pope, the "bloodthirsty Spaniard," and the Turk.

Two late mathematico-theological treatises from Pont's pen also exist. A New Treatise of the Right Reckoning of Years and Ages (Edinburgh, 1599) attacked Roman 
Catholic claims for the year 1600 and demonstrated that the End of the World was not far off, while De Sabbaticorum Annorum Periodis Chronologica (London, 1619) ${ }^{38}$ deals with the Book of Revelation. Pont's congregation at St Cuthberts included John Napier of Merchiston, inventor of logarithms and author of the international bestseller A Plaine Discoverie of the Whole Revelation (Edinburgh, 1593). Like his mathematician parish minister, Napier also wrote verse; A Plaine Discoverie contains the sole surviving examples. Robert Pont's much more extensive poetic remains, like those of many another Scottish divine, are mainly in neo-Latin verse. The six psalm paraphrases-his earliest known published writings - are his only known foray into vernacular verse. ${ }^{39}$ Their first stanzas are set out in Appendix B, in parallel with their English equivalents by John Hopkins. Pont's Ps 57 to its originally French tune ${ }^{40}$ and Ps 59 to its 1562 English tune are not particularly distinguished, but his text for Ps 76 works well to its (German 1524) tune. Pont's anapaestic text of Ps 80 sings hauntingly to its (German 1524) tune, and in Ps 81 Pont displayed considerable ingenuity in fitting his text to the splendidly quirky French tune used for Marot's Ps $33 .{ }^{41}$ The magnificent, long-breathed 1564 tune for Ps $83^{42}$ is also French in origin:

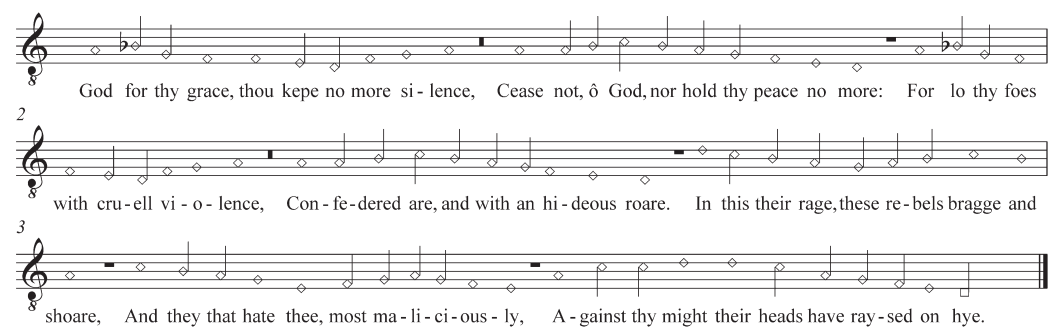

Pont's text of Ps 83 is quite different from that of the 1562 Whole Booke (accessible in ЕЕво), where Hopkins's text is directed to be sung to the melody appointed in both England and Scotland for Ps 77 (the contents whereof bear no relation to those of Ps 83): ${ }^{43}$

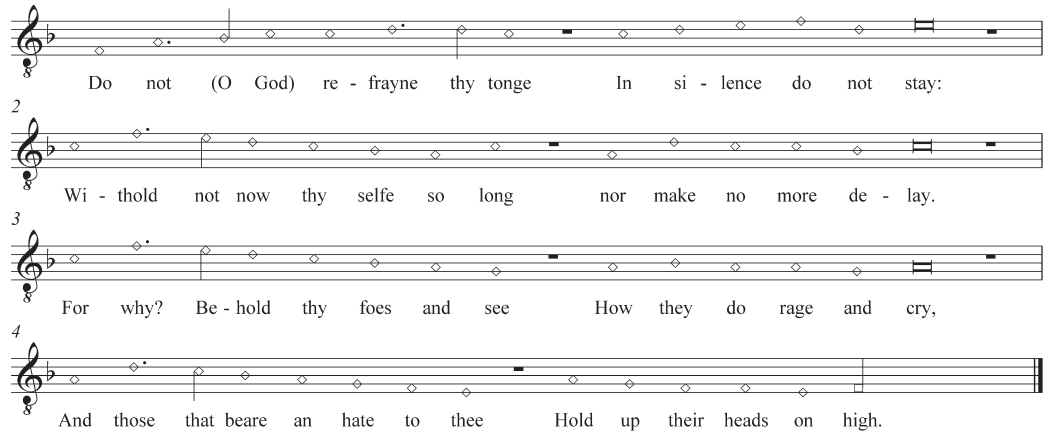


Both the Scottish and English metrical texts and tunes are quite independent of the Huguenot psalter (text by Theodore Beza):

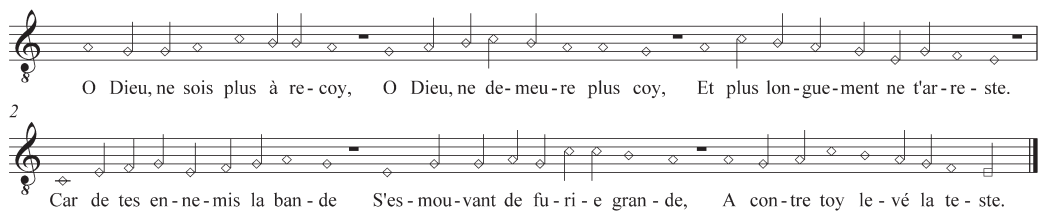

The tune of Scottish Ps 83 had first appeared in the Huguenot psalter of 1551, to be sung to Marot's paraphrase of Ps 10. (The Scottish psalter version of the tune introduces some rhythmic changes, and a slight melodic change in the last line):

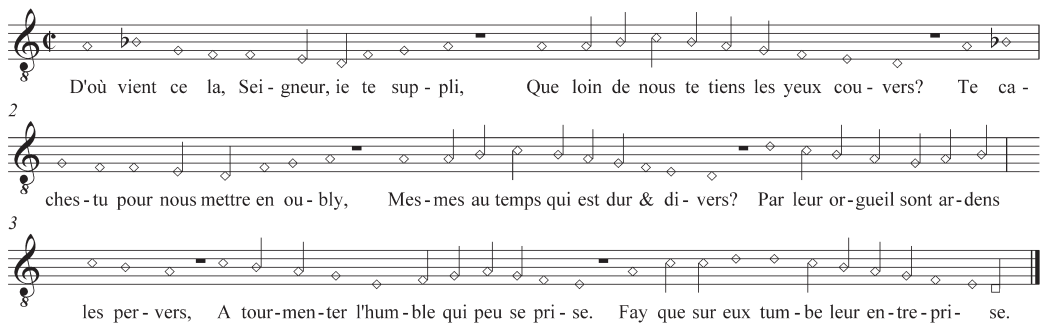

2. Car le malin se vante, \& se faict seur,

Qu'en ses desirs n'aura aulcun defaut;

Ne prisant rien que l'auare amasseur,

Et mesprisant l'Eternel de la hault.

Tant il est fier, que de Dieu ne luy chaut:

Mais tout cela, qu'il pense en sa memoire,

C'est, Dieu n'est point, \& si ne le veut croire.

Clearly, Psalm 10's prayer for deliverance from (and the destruction of) oppressive enemies would roll gratefully off protestant tongues; these sentiments are also found in Ps 83, a similarity which may explain why the anonymous versifier of the Ballatis Ps 83 chose Ps 1o's tune and Marot's rhyme-royal stanza form.

However far Robert Pont's efforts as a metrical psalmist fall short of Clément Marot's, they were clearly well regarded within the Kirk, for as late as 1601 , the General Assembly responded to King James vi's urgent request for a revision of the psalter by ordaining that Robert Pont, by then the kirk's most senior figure, the only surviving cleric from the heroic days of the Reformation, "sould revise the psalmes, and that his labours sould be revised at the next assemblie." 44 The Assembly noted that the great poet Alexander Montgomerie "and others" had made metrical versions as examples of what could be done, but that these were deemed unacceptable because congregations had memorized the existing official versions. ${ }^{45}$ Predictably, 
nothing came of the proposed revision, which appears to have been a mere ruse to prevent the king from interfering with worship, and perhaps trying to introduce his own metrical paraphrases. When in 1631 Charles I attempted to impose his father's (supposed) versifications for use in church, he called forth a barrage of criticism and was forced to withdraw the texts for revision. ${ }^{46}$ The depth of Scottish attachment to the 1564 psalter is revealed by the labours of Edward Millar, of the Scottish Chapel Royal: in 1635, after years of preparation, he brought out the first (and only) printed edition in which all the psalms were presented in four (or five) part harmony. ${ }^{47}$ When Charles tried, in 1637, to impose the new Scottish Prayerbook and the revised version of his father's paraphrases, he called forth the National Covenant and the Wars of the Three Kingdoms, one of whose many outcomes was the 1650 Scottish metrical psalter and the demise of the old version of 1564 .

\section{Pont's Psalm 83 and The Gude and Godlie Ballatis}

Appendix A presents the two versions in parallel, with corresponding lines aligned as closely as feasible, to show just how extensively Pont has modelled his bibeltreu, English-language version on the Ballatis Scots-language troped paraphrase. All the various enemies of Israel enumerated by the psalmist are identified in the Ballatis version with various parts of the Roman hierarchy and its political allies, resulting in a poem whose 70 lines make it three entire stanzas longer than that of 1564 . Two of the Ballatis tropes highlight the extent to which the paraphrase affirms the continuity of the "traditional" discourse of Scottish Protestantism: the Agarins "with hurklit hude ouer a weill nuresit neck" and Iabell and Amon who "iouk and beck" echo "Hurkland with hudes into our neck/ Wyth Judas mynd to jouck and beck" in the Earl of Glencairn's biting satire on pilgrimages, "Ane Epistle direct fra the Holye Armite of Allarit," recorded by Knox in his History under the year $1540 .{ }^{48}$ Ps 83 thus forms part of of the fight for Protestantism in pre-Reformation Scotland; thanks to Pont's revising it for the inclusion in the official psalter, these historical associations are carried over into the new Scotland, and the psalm now depicts the international protestant "true church" beleaguered by the hostile forces of Antichrist, a vision which would dominate Scottish spirituality right into the early $18^{\text {th }}$ century. The Ballatis paraphrase is narrower in scope: the persecuted Scots protestant "saints" are caught in an encircling noose of Catholic powers, allied "togidder in ane band/ quhilk neuer befoir culd gre amang thame sell.” This image does not fit the post-156o situation after the death of the Scottish regent, Mary of Guise. 
It better reflects slightly earlier circumstances. The "dum Doctouris of Tyre/ Quhilk dar not dispute, bot cryis, fyre, fyre" were extremely topical in Scotland and England up to 1558. Walter Myln was burned by the Archbishop of St Andrews in April that year. The reference to the Catholic refusal to "cum to na Counsell Generall”- something early protestants long clamoured for-would presumably refer to the long gap between the second and third sessions of the Council of Trent, when Paul IV refused to reconvene the Council and carried on the Counter Reformation through committees in Rome, partly because he was afraid of losing his "pomp pontificall" to the political machinations of nationalistically-minded bishops operating at the behest of their monarchs. ${ }^{49}$ But the reference to the "band" of hitherto mortal enemies united against the faithful saints is ideally appropriate to $2^{\text {nd }}$ and $3^{\text {rd }}$ April 1559, when Scotland really was encircled by the peace treaties of Cateau-Cambrésis between France, Spain, and England, ending years of hostilities, and marking a royal marriage alliance between France and Spain, declaring their joint intention to combat heresy. For though Elizabeth Tudor was known to be a protestant, her Settlement was not voted through Parliament until 28 April, and she did nothing at all to help Scottish protestants in their losing battle with Mary of Guise until January 1560. To 1559 also belongs, as shown by its reference to the Lords of the Congregation, the (in)famous Ballatis rant "The Paip, that Pagane full of pryde," which like Ps 83 , but in an altogether more gleeful vein, lists functionaries of the Roman Church. The 1897 Ballatis editor, A. F. Mitchell, highlights the French antecedents of "The Paip, that Pagane" in a 1555 Huguenot song "Contre le Pape et ses suppôts." ${ }^{\circ}$ It is possible that the two songs joined the Ballatis repertory at the same time. Indeed, they may even have flowed from the same unknown Francophile pen, and perhaps it was wielded by Robert Pont himself, whom the late Sermons against Sacrilege show to have been no mean polemicist. This hypothesis would go some way towards explaining why Ps 83 , alone of the Ballatis psalms, survived into the new kirk psalter.

Mitchell notes that both versions sing to the same melody, but nowhere comments that this melody is French. ${ }^{51}$ Mitchell was almost obsessively interested in the Germanic antecedents of the Ballatis, and managed to find an interesting Zürich analogue for the Scots Ps 83. But Helena Mennie Shire showed how much the Ballatis also draw on French sources, as Alasdair MacDonald likewise notes. ${ }^{52}$ Curiously, however, Shire too failed to comment on Ps 83's French melody. Appendix A shows Mitchell's observation that "the tune and even several of the words" of the earlier version "were retained in Knox's Psalter" 53 to be a gross understatement. Pont, while keeping closely to the Genevan prose translation of the Hebrew, manages 
to retain a great deal of the older text. Several of his changes are simply due to his need to eschew Scots words and rhymes, while he goes to some lengths to weave in individual phrases and words from the older recension, e.g. "maliciously" in 1.6 derives from Sisera's "maliciousnes" in the Ballatis, while 1.46 "And lat thame knaw" is taken from Ballatis "Lat them knaw," not the Geneva Bible's "That they may know," which would also have fitted the melody. But most strikingly, Pont retains "Ceis not" in 1.2, to the detriment of the line's clarity. He wanted his readers to recognize the source of his paraphrase-and its tune.

That tune would have been recognized not only by Scots who had been actively committed to reform before the Reformation Parliament abolished the mass, but by Frenchmen. The French courtier Pierre de Brantôme was one of the distinguished party which accompanied Queen Maryback to her native kingdom, and he recorded a famous bout of very public Scottish psalm-singing that took place in Edinburgh on the queen's first night at Holyroodhouse, 19 August 1561. The Catholic monarch and her French company were serenaded with "pseaumes si mal chantez et si mal accordez que rien plus" sung by "cinq ou six cents marauts de la ville" to "meschans viollons et petits rebecz" under the queen's window. "Quelle musique et quel repos pour sa nuict" was Brantôme's comment on this populist charivari, which gave Mary a foretaste of what she would face in slightly more sophisticated form on 6 September, in the shape of the extraordinary anti-Catholic propaganda exercise of her "Joyeuse Entrée" into her capital, during which psalms were sung. ${ }^{54}$ For, as Peter Davidson has pointed out, "the singing of metrical psalms in itself would register with the queen's French entourage as a specifically protestant demonstration." 55 Davidson wishes to argue for Whittingham's Ps 124, written in 1558 to the French melody for that very psalm ${ }^{5}$ - which Brantôme and his companions would have recognized, as they would have recognized the tune of French Ps 10. And if Ps 83 was sung in August 1561 by the "scoundrels from the town," it would surely have been the earlier version, with its denunciation of monarchs whose "conscience is thrall/ To thame quhilk hes na hope celestiall, / Bot contrair God indurit hes thair hartis/ Syne sylie Princes, blindly, tak their partis." Quelle musique et quel repos pour sa nuict, indeed.

\section{Conclusion: Ps 83 and the Bannatyne Manuscript}

We have seen that George Bannatyne, unlike Knox and the Edinburgh city authorities, adopted an Erasmian tone in his "Ballatis of Theoligie," and avoided openly anti-Roman material. After three splendid long lyrics by John Bellenden and Gavin Douglas, senior clerics of the Scottish Catholic Church in the early decades of the 
$16^{\text {th }}$ century, and the barely non-confessional Ballat of the creatioun of the warld by the civil servant Sir Richard Maitland, who never conformed to Protestantism, Bannatyne placed Robert Pont's Ps 83. With 150 official metrical psalms to choose from, the choice of Pont's carefully bibeltreu and hence confessionally neutral revision of the Ballatis Ps 83 is highly significant, and not least in the ongoing debate about whether the Bannatyne Manuscript is in some sense, as Alasdair MacDonald argued as early as 1986, "A Marian Anthology." 57 By the time Bannatyne completed his Manuscript with its fivefold organization and its alphabetical index, Mary had fallen; but there was no knowing what might happen. Elizabeth Tudor might well restore the anointed Queen of Scots. Even if Bannatyne were only ever proposing "manuscript publication," he would have to consider the sensibilities of his many potential Catholic and crypto-Catholic readers. Edinburgh was full of them, and would remain so for many years to come, even in the top ranks of the mercantile and legal professions..$^{8}$ The complete absence from the Bannatyne Manuscript of overtly reforming material is striking; entirely unrepresented are not only the Lutheran texts from the Gude and Godlie Ballatis, but even Sir David Lyndsay (other than by the religio-politically neutral "mirry interludes" of the Satyre of the Thrie Estaitis).

It can reasonably be postulated that Bannatyne chose to set Pont's Ps 83 very near the beginning of his opening section "contenand ballatis of theoligie" precisely because it could be read in two entirely opposite ways. Ps 83 's impact on Bannatyne's readers would have been not dissimilar to that of the English recusant composer William Byrd's 8-part'Quomodo cantabimus' on his contemporaries. Byrd's motet sets part of Ps 137, and English Protestants, with their tradition of self-identification with the Babylonian Captivity, would misread the composer's intent, while the latter's fellow-Catholics would automatically hear the text the other way around. 59 In a similar way, Scotland's currently triumphant Protestants would read the inclusion of Pont's Ps 83 as affirming Bannatyne's reformed sympathies, for here was the new Kirk's official text, unimpeachable in its deafeningly loud "gude and godlie" associations with the heroic struggle to overthrow the Roman tyranny, in Scotland and elsewhere. The now-beleaguered Catholics, and their sympathizers, on the other hand, could read the psalm exactly as the pre-Reformation Protestants had done: a prayer for divine deliverance from utter destruction at the hands of hostile oppressors. Given the markedly traditional (i.e. catholic) nature of three of the four poems that precede it, and of so many of those that follow, ${ }^{60}$ Ps 83 would to a Catholic reader stand as a prayer for the restoration of the old spiritual order and its certainties_-an order of whose revenues, buildings and lands the new-minted 
Protestant nobles were (as the aged Robert Pont would lament decades later in his Three Sermons against Sacrilege) quite literally saying, "Lat ws inhereit as our awin Godis mansionis.”

\section{APPENDIX A}

To minimize orthographical differences, Pont's text is given from a unique copy of a Scots-orthography psalter edition of c.1578. ${ }^{61}$ The few, insignificant verbal (as opposed to orthographical) differences between the printed 1564 text and Bannatyne's copy are indicated thus: [italics]

\section{Gude and Godlie Ballatis (1567 text)}

Deus quis similis erit tibi Psal. Lxxxiij

God, for thy grace, thow keip no moir silence, Ceis not to send thy Sanctis sune support, Postpon it not, but haist thy vengeance On Hypocrites, humlie I the exhort:

For thay Rebellis with rage do resort,

And thay quhilk at the haif mortall feid, Contrair thy mycht hes liftit up thair heid.

And till oppres thy people do pretend, Under precept and cloikit halynes, With subtell slycht to slay vs thay intend. Confiderat thay ar, baith mair and les, Contrair thy testament, our hope \& richteousnes; Thay say, thay sall us rute from the ground. That na mentioun of vs sall mair be found.

Thay now conspyre with cruell hart and fell, With ane consent, togidder in ane band, Quhilk neuer befoir culd gre amang thame sell, Stryuand for stait and hicht in euerie land. But contrair the togidder stiffe thay stand. And fast lyke burris, thay cleif baith ane and all, To hald, O God, thy word and vs in thrall.

Ze Edomitis Idoll, with thrinfald Crowne,

\section{Robert Pont: Ps LXXXIII}

Deus ne sit silentium tibi, ne sileas.

$i$ God, for thy grace thow keip no moir sylence, Ceis not, O God, nor hald thy peice no moir: ii For lo thy fais with cruell violence Confiderit ar, And with ane hiddeous roir In this their rage thir [thaye] rebellis bragge and schoir,

And they that hait the maist maliciously

Against thy micht thair heidis haue raisit [hes raisd] on hie.

iii For to oppres thy pepill they pretend,

With subtill slicht: and mufe conspiracie: For sic as on thy secreit help depend, iv Go to, say thay and let vs vtterly This Natioun, rute out from memory: And of the Name of Israelites let neuer Farther be maid na mentioun for euer. $v$ Conspyrit ar with cruell hartis and fell, Thus aganis thee togidder in a band.

$v i$ The Edomites that in their tents do dwell. 
The crop and rute of pryde and Tyrannie,

Ze Ismaelitis, with scarlat hat and gowne,

Zour bludie boist na syith can satisfie,

Ze Moabitis, with hornis twa full hie,

And Ismaelites joynit with thame to stand:

Outward, lyke scheip, ze beir the beistis mark,

Inwart, lyke tykis ze byte, but can nocht bark.

Of Agarins quhat tung can tell the tryne,

With hurklit hude ouer a weill nureist neck?

Iabell and Amon, als fat as ony swyne,

Quhilk can not do, bot drink, sing Iouk \& beck;

The Amalekis, that lesingis weill can cleck.

The Palestinis, with dum Doctouris of Tyre,

Quhilk dar not dispute, bot cryis, fyre, fyre.

Assure in harnes is with thame euer moir,

Companzeoun he is perpetuall

To Lotis Sonnis, for to mantene thair glore;

He wate nocht ellis, for his conscience is thrall,

To thame quhilk hes na hope celestiall,

Bot contrair God indurit hes thair hartis

Syne sylie Princes, blindly, tak thair partis.

O God of gloir resist thair cruelnes,

As thow sum tyme ouerthrew the Madionitis

And Sicera, with his maliciousnes,

And Iabene with his bludie Hypocritis,

At Kysone flude, as weill the story dytis:

Thay perischit at Endor throw thy mycht

Syne muk become, and fylth, for all thair hicht.

Thair gouernouris and gydis gif sicklyke,

As Oreb, Seb, Seba and Zelmanie,

Thair sinnis schawis thay ar a bludie byke.

And zit thay wald, throw thair Hypocrisie,

Posses the Kirk of God, throw tyrannie,

And will cum to na Counsell Generall,

For feir thay lose thair pomp pontificall.

The Moabites vpon the vther hand,

With the proud race of Agarens togidder

Assemblit ar and wickitly confider [considder].

vii Geball, Ammon and Amalek all three:

Marche furth ilkane with his garison.

The Philistims formest they think to be,

The Indwellers of Tyre with them ar boun

viii Ashur also is their companzeoun

With the Children of Lot, to be arrayit

In their support his banner is displayit.

$i x$ Do thow to them as thow did to the Hoist,

Of Madian Jabin and Sisera

$x$ At Kyson flude. In Endor lyfis they loist

To doung the land quhair as thair bodyis lay.

$x i$ Like Oreb, Zeb, Zeba and Zalmunna

Sa mak thow them euin their maist mychtie

Princes

And all the chief rewlers of their Prouinces

$x$ ii Quhilk said, Let us inherit as our awin

Gods Mansiouns. xiii My God mak them to be

As quheill vnstabill and caffe befoir the wind, And as the wod consumit is with fyre;

And as the flame burning, quhair it can fynd The faggat, in the feild, with greit Impyre:

Like rolling quheilis or as the stuble blawin Befoir the wind. xiv As fyre the wodes [wid] we se, Dois burne; and flame deuoir on Montaines hie 
Siclyke persew thame with thy greuous ire,

Lat thy tempest thair wraithfulnes reuenge,

The heder crop, $x v$ Sa let thy tempest chais them,

And lat thy storme thair pryde in purteth change. And thy quhirle wind with terrour sa deface them.

Confound thame, Lord, that thay may seik thy name,

Perturbe thair mynde with cair continuall.

And lat thame perische \& cum till vtter schame:

Lat them knaw the, for the God eternall,

Allanerlie on the allone to call,

And the obey, abone all eirdlie thing,

Maist michtiest, maist hiest in thy Ring. $x v i$ Thair faces, Lord, with schamefulnes fullfill:

That they may seik thy Name in mynd to prent. $x v i i$ Confoundit let them be, and euer still Vexit with wo, yea, mak thame schamde \& schent; xviii And let thame knaw that thou art permanent: That Jehoua thy Name alone pertenis To the over all the erth quhais glorie reignis.

\section{APPENDIX B}

John Hopkins: Whole Booke of Psalmes, 1562

LVII

Take pittie for thy promise sake Have mercy Lord on me.

For why? My soule doth her betake

Vnto the help of thee.

Within the shadow of thy wings

I set myselfe full fast:

Till mischiefe, malice and like things

Be gone and ouerpast.

LIX

Send aide and saue mee from my foes

O Lord I pray to thee

Defend and help me from all those

That rise and striue with me.

O Lord preserue me from those men

Whose doings are not good

And set me sure and safe from them

That still thirst after blood.
Robert Pont: Psalms for the Scottish Metrical

Psalter (1564 printing)

LVII

Be mercifull to me, O God, be mercifull to me, For why? My soule in all assaultes Shall euer trust in thee; And till these wicked stormes be past Which ryse on euerie syde, Vnder the shadow of thy winges My hope shall always byde.

LIX

Deliuer me, my God of might

From danger of mine enemies, And me defend in this my right From all that do against me rise. Deliver me from them that haue Delyte to work iniquitie And from these bloodie men me saue That seeke my soule with crueltie. 
LXXVI

To all that now in Iury dwell

The Lord is clearly knowne:

His name is great in Israel

A people of his owne.

At Salem he his tents hath pight

To tarrie there a space

In sion eke he hath delight

To make his dwelling place.

$\operatorname{LXXX}$

Thou herd that Israell doest keepe

Giue eare and take good heed,

Which leadest Josephe like a sheepe,

And dost him watche and feede.

The Lord I say, whose seat is set

On cherubim so bright

Shew forth thy self and do not let

Send down thy beames of light.

LXXXI

Be light and glad, in God rejoyce, Which is our strength and stay,

Be joyful and lift vp your voice

To Jacobs God I say,

Prepare you instruments most meete

Some joyful psalme to sing

Strike vp with harpe and lute so sweet,

On every pleasant string.
LXXVI

In Iury land God is well known

In Israell great is his name;

He chose out Salem for his owne

His tabernacle of great fame

Therein to raise: \& mount Sion

To make his habitation

And residence within the same.

LXXX

O Pastor of Israell, like sheep that dost lead

The linage of Iosephe, aduert \& take heed;

That sittest between the Cherubin bright

Appeare now and shew to vs thy great light.

\author{
LXXXI \\ To God our strength most comfortable \\ With merrie hearts sing and rejoyce \\ To Iaakobs God most amiable \\ Make melodie with chearfull voyce. \\ Goe take vp the psalmes \\ The timbrell with shalmes \\ Bring foorth now let see \\ The harpe full of pleasure \\ With viole in measure \\ That well can agree.
}

\section{Notes}

My thanks to Mick Swithinbank for the music examples, and to Kenneth Elliott, Elizabeth Henderson, Alasdair MacDonald, Joseph Marshall, and John Purser for kind assistance in locating texts and information.

1. This triple coincidence has hitherto been noted only in A. F. Mitchell, The Gude and Godlie Ballatis (Edinburgh and London: Scottish Text Society, $\mathbf{1}^{\text {st }}$ series, 1897), p. 260; Sally Mapstone, Scots and their Books (Oxford: Bodleian Library Publications, 1996), p. 26, notes the 1564 Psalter text's presence in the Bannatyne Manuscript. The Bannatyne Manuscript, ed. W. Tod Ritchie, Scottish Text Society, 4 vols. (Edinburgh and London: Blackwood and Sons, 1928-34). Psalm 83 is found on folio 14 rv, i.e. Tod Ritchie, vol.2, p.33-34. There is also a facsimile edition: The Bannatyne Manuscript: 
National Library of Scotland Advocates' MS. 1.1.6., Intro. Denton Fox and William A. Ringler (London: Scolar Press, in Association with The National Library of Scotland, 1980).

2. Alasdair A. MacDonald is preparing a much-needed new scholarly edition for the sTs, based on the 1565 print.

3. MacDonald, in "The Early Reception of German Literature in Scotland," in Literatur-Geschichte, Literaturgeschichte, Festschrift für Volker Honemann (Frankfurt: Peter Lang, 2003), pp. 263-76, considers all the historical factors and background. John Knox, in his History of the Reformation in Scotland, cites one of its psalm versions as being sung in 1546, in Works (6 vols.) ed. D Laing (Edinburgh: Wodrow Society, 1846-64), vol. 1, p. 139.

4. David Calderwood, History of the Kirk of Scotland, ed. T. Thomson, 8 vols. (Edinburgh: Wodrow Society, 1842-49), vol. 4, p. 352.

5. Ps $2,12,13,15,23,31,33,37,51,64,67,73,79,83,91,114,124,128,130,137,145$ (the prints use a chaotic mixture of Massoretic, Vulgate, and simply wrong numberings); Alasdair MacDonald informs me that the 1565 print (sole copy held in Göttingen University Library) also included two English psalms which disappeared from subsequent editions, namely Thomas Sternhold's original version of Ps 1 (i.e. as printed up to 1553 , and therefore not as in the 1564 Psalter), and John Hopkins's Ps 146, as it appears in both the English and Scottish official psalters.

6. Mitchell points out in his 1897 edition, p. lv, that its baptismal trope of amplius laua me contains "expressions in regard to the general effects of baptism stronger than many Scottish Protestants would now use."

7. Many of the Ballatis psalms could have lent themselves to explicitly protestant troping, but such is only found in the anti-prelatical comments of the last verse of Ps 12, a Luther translation (see Mitchell, p. 256).

8. In addition to Mitchell, see H. M. Shire, Song, Dance and Poetry of the Court of Scotland under King James VI (Cambridge University Press, 1969), pp. 25-33; Brian Murdoch, "The Hymns of Martin Luther in the Gude and Godlie Ballatis," in Studies in Scottish Literature 12 (1974-75), pp. 92-109. See the following works by A. A. MacDonald: "Religious Poetry in Middle Scots" in R. D. S. Jack, ed., The History of Scottish Literature, I (Aberdeen: Aberdeen University Press, 1988), pp. 91-102; "The Gude and Godlie Ballatis (1597): a Ghost No More?, Edinburgh Bibliographical Society Transactions 6 (1993-1995), pp. 115-131; "Contrafacta and the Gude and Godlie Ballatis” in H. Wilcox, R Todd and A. MacDonald, ed., Sacred and Profane: Secular and Devotional Interplay in Early Modern British Literature (Amsterdam: VU University Press, 1996), pp. 33-43; "The Early Reception," pp. 263-76; "On first looking into the Gude and Godlie Ballatis (1565)” in Sally Mapstone, ed., Older Scots Literature (Edinburgh: John Donald, 2005), pp. 230-42.

9. Ps 137 is briefly discussed in R. J. Lyall, "Alexander Allan (Alesius) and the development of a Protestant Aesthetics," in G. Caie, R. J. Lyall, S. Mapstone and K. Simpson, ed., The European Sun (East Linton: Tuckwell, 2001), pp. 368-80 (377-78). Millar 
Patrick, Four Centuries of Scottish Psalmody (Oxford University Press, 1949), pp. 5-8, speaks highly of the psalm paraphrases, while William MacMillan, The Worship of the Scottish Reformed Church, 1550-1638 (London: James Clarke, 1931), pp. 15-22, is disparaging and inaccurate. The Ballatis psalms are not mentioned at all in, for example, Gordon Donaldson, The Scottish Reformation (Cambridge University Press, 1960) nor, despite coverage of music, literature and worship (including mention of both the Bannatyne Manuscript and the Gude and Godlie Ballatis), in J. Wormald, Court, Kirk and Community: Scotland (London: Edward Arnold, 1981), or M. Lynch, Scotland, a New History (London: Pimlico, 1991, rev. edn. 1992), though the former does speak of the impact of post-Reformation psalm-singing.

10. But see A. G. Gilchrist, "Sacred Parodies of Secular Folk Songs: a Study of the Gude and Godlie Ballatis," Journal of the English Folk Dance and Song Society 3 (1937-39), pp. 157-82.

11. Patrick, pp. 45-46, gives the most circumstantial account of the delay. Calderwood's abridged History of the Kirk of Scotland (Rotterdam, 1678), p. 39, mentions that the General Assembly of 25 December 1564 ordained that every minister, exhorter and reader should have one of the psalm books lately printed at Edinburgh. The matter of the psalms had been considered by a General Assembly in December 1562, two years after the First Book of Discipline had been drawn up (J. K. Cameron, ed., The First Book of Discipline, [Edinburgh: St Andrew Press, 1972], p. 9).

12. Patrick devotes pp. 45-63 to "The First Scottish Psalter, 1564," and pp. 79-205 to its 1650 successor.

13. R. R. Terry's The Scottish Psalter of 1635 (London: Novello, 1935) is a reprint, minus 115 pages of preliminary “dissertations," of Rev. Neil Livingstone's The Scottish Psalter of 1635 (Glasgow, 1864); Maurice Frost, English \& Scottish Psalm \& Hymn Tunes c.1543-1677 (sPCK and Oxford University Press, 1953) is a priceless bibliographical resource. For other publications see those listed in J. Reid-Baxter, "Thomas Wode, Christopher Goodman and the Curious Death of Scottish Music," in Scotlands 4.2. (Edinburgh University Press, 1997), pp. 1-20, fn.1.

14. This applies to two recent major studies: David Mullan, in Scottish Puritanism 1590-1638 (Oxford University Press, 2000), makes no reference to the metrical psalms, while Margo Todd, in The Culture of Protestantism in Early Modern Scotland (New York and London: Yale University Press, 2002), pp. 70-73, discussing the popularity of metrical psalmody, appears to identify the Scottish psalter with the English Whole Booke.

15. The virtuosic psalm paraphrases of the anonymous Mindes Melodie (Edinburgh, 1605), for example, bristle with adroit quotations from the 1564 psalter, while Elizabeth Melville's Ane Godlie Dreame (Edinburgh, 1603) quotes metrical Ps 22.13 in 1.47, Ps 71.2 in 1.55, Ps 143.6 in 11.85-86, Ps 91.4 in 1.304 and Ps 60.4 in 11.452-56. See also next note.

16. In D. J. Parkinson, ed., Alexander Montgomerie: Poems (Edinburgh: Scottish Text Society, $4^{\text {th }}$ Series, 200o), it is not noted that Poems 1.16 and $27 ; 2.11,32-33$ and $44 ; 64.6$; 98.1 and 3 directly quote metrical Pss.1.13 and 25; 2.15, 33, 35 and 38; 101.1 and 34.11 respectively. 
17. E.g. R. J. Lyall, Alexander Montgomerie, Poetry, Politics, and Cultural Change in Jacobean Scotland (Tempe: Arizona Centre for Medieval and Renaissance Studies, 2005), p. 285, claims that "Calderwood evidently supported the continued use of the Sternhold and Hopkins Psalter.”

18. Wormald, pp. 181, 189; Lynch, New History, pp. 213, 260, 459n.

19. See the following by A. A. MacDonald: "Poetry, Politics and Reformation Censorship in Sixteenth-Century Scotland," English Studies 5 (1983), pp. 410-21; “The Bannatyne Manuscript-a Marian Anthology,” The Innes Review 35 (1986), pp. 36-47; “The printed book that never was: George Bannatyne's poetic anthology," in J. M. M. Hermans and K. van der Hoek, Boeken in de late Middeleeuwen. Verslag van de Groningse Codicologendagen 1992 (Groningen: Egbert Forsten, 1994) pp. 101-10; "Scottish Poetry of the Reign of Mary Stewart," in The European Sun (2001), pp. 44-61 (55-58); "The Cultural Repertories of Middle Scots Lyric Verse," in G. K. Dorleijn and H. L. J. Vanstiphout, ed., Cultural Repertoires. Structure, Function and Dynamics (Leuven: Peeters, 2003), pp. 59-86 (74-84). MacDonald's view of the Manuscript is challenged by Priscilla Bawcutt, "Scottish Manuscript Miscellanies from the Fifteenth to the Seventeenth Century," English Manuscript Studies 12 (2005), pp. 46-73 (46-47, 60-64); see Mapstone, ed., Older Scots Literature, pp. 180-210 for another version of this essay.

20. Theo van Heijnsbergen, "The interaction between Literature and History in Queen Mary's Edinburgh: the Bannatyne Manuscript and its Prosopographical Context," in A. A. MacDonald, M. Lynch and I. B. Cowan, ed., The Renaissance in Scotland: Studies in Literature, Religion, History and Culture offered to John Durkan (Leiden: Brill, 1994), pp. 183-225.

21. MacDonald, "Cultural Repertory," p. 84.

22. See van Heijnsbergen, pp. 222-23. These links are explored in far greater detail in his forthcoming $\mathrm{PhD}$ thesis on Alexander Scott.

23. Alasdair MacDonald (private communication) has pointed out that the solitary survival of one copy of the 1565 edition printed by John Scot for Thomas Bassandyne could indicate that the Kirk may have attempted to have the edition destroyed because it contained official Kirk psalms, which must have enraged Robert Lekprevik, the Kirk's official printer (see note 5 above and MacDonald “Scottish Poetry," p. 55). The 1567 Ballatis, thanks to the inadvertent inclusion of a secular love song, certainly drew furious protests from the General Assembly (see MacDonald, "Contrafacta," pp. 37-38).

24. See note 3, above. Alasdair MacDonald, "Scottish Poetry," p. 54, is extraordinarily cautious about accepting Knox's claim. The Ballatis psalms would not have been all that was available before 1560. The presence of the pre-1553 Sternhold version of Ps 1 in the 1565 Ballatis lends support to Millar Patrick's claim that "Sternhold and Hopkins's first collection of twenty four Psalms without music had found its way northward about $1550 "$ (p. 46).

25. See the relevant notes to each psalm in Mitchell. 
26. Christopher Goodman of Chester, Knox's closest friend, clearly learned to speak Scots in order to work in Scotland from September 1559 to November 1565; in October 1566 Knox wrote to him in Ireland that "I wold not that ye shulde forgett your Scotish toung” (J. E. A. Dawson \& L. K. J. Glassey, “Some Unpublished Letters from John Knox to Christopher Goodman," Scottish Historical Review 84 (2005), pp. 166-201, at 184-85).

27. See Pierre Pidoux, Le Psautier Huguenot, 2 vols. (Basle: Bärenreiter, 1962).

28. M. M. Knappen, Tudor Puritanism (University of Chicago Press, 1939; Phoenix edition, 1965), p. 389; the phrase had a long life ahead of it: George Wither claimed in 1619 that Catholics mocked the Psalms as "Geneua Iiggs, and Beza's Ballets" in A Preparation to the Psalter (London, 1619), p. 8. Richard Watson, The Right Reverend Doctor John Cosin (London, 1684) uses the phrase on p. 32 of his tirade against metrical psalmody. My thanks to Alec Ryrie for a copy of his paper on Biblical piety and metrical psalmody, given at the British Academy, 8 September 2007.

29. R. A. Leaver, Goostly Psalmes and Spirituall Songs: English and Dutch Metrical Psalms from Coverdale to Utenhove (Oxford: Clarendon Press, 1991), p. 256, is completely unaware of this fact, stating that the Scottish psalter "was essentially the 1561 AngloGenevan, with material taken from the 1562 English complete psalter to make up the 150 psalms." Leaver appears to have looked only at the anomalous psalter "imprimé pour Henri le Mareschal” in 1566 (sTC 16578; see Frost, pp. 18-19).

30. See Patrick, pp. 47-49, and John Row, History of the Kirk of Scotland (Edinburgh: Wodrow Society, 1842), pp. 415-17 and 457-62.

31. See Ian C. Cunningham, ed., The Nation Survey'd: Timothy Pont's Maps of Scotland (East Linton: Tuckwell, 2001).

32. See for example Arthur Williamson, "Number and national consciousness: the Edinburgh mathematicians and Scottish political culture at the union of the crowns," in Roger Mason, ed., Scots and Britons: Scottish Political Thought and the Union of 1603 (Cambridge University Press, 1994), pp. 187-212, at 193-97.

33. See Diane Baptie, The Pont family: a detailed report, <http://www.nls.uk/pont/bio/ ponts_family.pdf> (date accessed: 20 September 2007), part 1, under "Culross Abbey and Shiresmill.” The James (Kyn)Pont who was a distinguished monk of the Cistercian Abbey at Kinloss is thought to have been brought thither by Abbot Thomas Crystall, himself a former monk of Culross (J. Stuart, Records of the Abbey of Kinloss [Edinburgh, 1872], pp. xlvii, 39, 47, 62, 142, 149).

34. J. Ridley, John Knox (Oxford: Clarendon Press, 1968), p. 509.

35. See Arthur Williamson, Scottish National Consciousness in the Reign of James VI (Edinburgh: John Donald, 1979), pp. 66-67 and notes.

36. Three Sermons against Sacrilege (Edinburgh, 1599), “The First Sermon,” sig.B8b, sig.Cia.

37. Three Sermons, "The First Sermon," sig.A5.

38. Remarkably, the title page of the 1626 London print is adorned with the Virgin, crowned as Queen of Heaven, adored by men and angels, with the legend "Sigilla antiqui hospitalis sanctae mariae de bethlehem extra bishopsgate.” 
39. Parvus Catechismus carmine iambico (St Andrews, 1573; STC [2 $2^{\text {nd }}$ ed.] 20105 ) and Canticum Canticorum Salomonis [...] carminis heroici genere buccolico redditum (Edinburgh, 1604; STC [ $2^{\text {nd }}$ ed] 2765.5); also, inter alia, a liminary epigram (in selfdeprecation) to Patrick Adamson's Catechismus Latino Carmine (Edinburgh, 1581), a liminary epigram in Greek, with a Latin verse translation, to Hadriaan Damman's Schediasmata (Edinburgh, 1590), a fine "epitaph" in Vitae \& mortis D. Roberti Rolloci Scoti narratio (Edinburgh, 1599), and two vigorous panegyrics of 62 and 100 lines respectively, praising the union of Scotland and England at the end of his own De Unione Britannniae.

40. French 1547 for the Ten Commandments (see Frost, p. 207), appointed in all early Scottish psalters for Ps 57, although not actually printed in 1564/65. Harmonized for the Thomas Wode Partbooks by John Angus, after 1566. The other "Pont" tunes (see under the appropriate number in Frost) had been harmonized in four parts for Thomas Wode between 1562 and 1566 by David Peebles in St Andrews. Wode recorded a second four-part harmonization of Ps 76 on p. 162 of his later Duplicate Cantus (TWC 2), by Andrew Blackhall. A three-part harmonization of Ps 59 by Andrew Kemp is extant. On Wode, Angus, Blackhall, Kemp and Peebles, see Reid-Baxter, “Thomas Wode" (see note 13 above), and also Hilda Hutchison, The St Andrews Psalter, Edition and Commentary (Edinburgh University DPhil thesis, 1957). A rejoicing crowd the Cross of Edinburgh was apparently led in Ps 76 by the Rev. Robert Bruce on the occasion of the destruction of the Spanish Armada; see James Porter, "Blessed spirits, sing with me," in Defining Strains: the Music Life of Scots in the Seventeenth Century (Bern: Peter Lang, 2008), pp. 299-322, at 301. A. G. Gilchrist, "Psalm-Versions and French Tunes," Records of the Scottish Church History Society 5 (1935), pp. 208-13, at p. 12, is sharply critical of Pont's versions of Ps 81 and Ps 83 .

41. Also appointed for French Ps 57; all these psalms speak of rejoicing on musical instruments.

42. Peebles's haunting B minor harmonization, in which he flattens all the Bs of the originally "Dorian” tune, is sung by Paul Rendall (tenor) with Robert MacKillop (lute) on Thus Spak Apollo Myne: the Songs of Alexander Montgomerie, ASV CD GAU 249. The disc also features the tunes for Pont's Ps 59 and Ps 80.

43. The compilers of the psalter were not to know that the tune's final phrase would irresistibly remind modern listeners of annual carol services and "The Angel of the Lord came down and glory shone around."

44. Calderwood, History IV, 124

45. This is discussed by R. J. Lyall, Montgomerie, p. 286.

46. See Millar Patrick, pp. 80-88.

47. Much of it written 70 years earlier by David Peebles and others: see Kenneth Elliott, "Scottish Music of the Early Reformed Church," Transactions of the Scottish Ecclesiological Society (1961), pp. 18-32.

48. Knox, Works, vol. 1, pp. $72-75$ (73). 
49. Pierre Janelle, The Catholic Reformation (Milwaukee: Bruce Publishing, 1963), pp. 66-67.

50. Mitchell, pp. 293-94.

51. Bizarrely, Mitchell claims in his footnote on p. liii that the 1564 text is by John Craig, and on pp. 260-61, even more oddly, that "the intermediate version contained in the Bannatyne ms $[. .$.$] has several lines much nearer to it than the Knoxian Psalter has."$ On p. 260 he claims, tantalizingly, without providing sources, that Ps 83 "was to the persecuted Protestants in our native land what the Ps 78 was to the persecuted $\mathrm{Hu}$ guenots of France, Ps 66 to the Protestants of Germany, and Ps 124 to Knox and the Reformed Church after 1560."

52. Shire, p. 29; MacDonald, “The Early Reception,” p. 270.

53. Mitchell, p. liii

54. A. A. MacDonald, "Mary Stewart's Entry to Edinburgh: an Ambiguous Triumph," The Innes Review 42 (1991), pp. 101-10; Peter Davidson, "The entry of Mary Stewart into Edinburgh, 1561, and other ambiguities,” Renaissance Studies 9 (1995), pp. 416-429. After the closing pageant, in which a dragon was burned, a psalm was sung, and another after the final speech denouncing the Mass. Ps 83 would suit either occasion; it invokes the fiery vengeance of God on the Kirk's enemies, and the 1564 Scottish Psalter rubric describes it as "a prayer for the Church, being assaulted on all sides by the unfaithfull, confederated together to bring it to ruine."

55. Davidson, pp. 417-18.

56. This psalm was indeed sung, and in four part harmony, by some 2,000 individuals in the other major public mass psalm-singing event recorded, the triumphal return to Edinburgh of the banished minister John Durie on $4^{\text {th }}$ September 1582, marking the definitive overthrow of the regime of Esme Stuart, Duke of Lennox; see J. ReidBaxter, "The Nyne Muses, an Unknown Renaissance Sonnet Sequence," in A. A. MacDonald and K. Dekker, ed., Rhetoric, Royalty and Reality (Leuven: Peeters, 2005), pp. 197-218, at 197-98.

57. See note 19 above.

58. To name only two examples: Napier of Merchiston's uncle Andrew, merchant burgess, and Mr. Edmond Hay, advocate.

59. On Catholic reception of Byrd's Quomodo cantabimus and Deus venerunt gentes, see Joseph Kerman, "Music and Politics: The Case of William Byrd," APS Proceedings 144 (2000), pp. 275-87, at 278-80.

6o. The very next poem ends with the promise that the soul "efter daith Sall ressaif the rewarde/ Of werkis in lyftyme It did maist regarde," which does not exactly embody the Reformed doctrine of salvation by grace alone.

61. Not in Еeво. Stc ( $2^{\text {nd }}$ ed.) 16580.7 , no title page; no.149 in H. G. Aldis, A List of Books Printed in Scotland before 170o. It omits the tunes, but, oddly, features the Latin incipits of an unidentified edition ("Jehova" replaced by "Dominus") of the psalm translations of the Dominican Hebraist Sanctes Pagninus. 